\title{
An Enzymic Assay for the Determination of Millimicrogram Quantities of $B_{12}$-Coenzyme ${ }^{1}$
}

Dioldehydrase (1), an enzyme which catalyzes the conversion of 1,2propanediol to propionaldehyde in the presence of $\mathrm{B}_{12}$-coenzyme," can be used to assay the coenzyme quantitatively. The assay is based upon the fact that the amount of propionaldehyde produced is directly proportional to the amount of $\mathrm{B}_{12}$-coenzyme present. The lower limit of the assay is $0.001 \mu \mathrm{g}$ of $\mathrm{B}_{1 \mathrm{x}}$-coenzyme. Vitamin $\mathrm{B}_{1::}$ and hydroxocobalamin, when present at twice the level of $B_{12}$-coenzyme, do not interfere with the assay. Other $B_{1:}$ derivatives are not expected to interfere, although they have not actually been tested.

Assay Procedure. The following reagents are used: $0.2 \mathrm{M}$ potassium phosphate buffer, $\mathrm{pH}$ 8.0, dioldehydrase (1), 10-12 units $/ \mathrm{ml} 0.01 \mathrm{M}$ $\mathrm{K}_{2} \mathrm{HPO}_{4}-2 \%$ 1,2-propanediol, and the reagents required for the aldehyde assay of Böhme and Winkler (2). The assay is carried out in $15 \times 125 \mathrm{~mm}$ test tubes. To each tube is added $0.2 \mathrm{ml}$ buffer and $0.6 \mathrm{ml}$ $\mathrm{B}_{12}$-coenzyme solution to be assayed or standard $\mathrm{B}_{12}$-coenzyme solution. The test tubes are kept in a $37^{\circ}$ bath. After temperature equilibration is reached, the reaction is started by the ardition of $0.2 \mathrm{ml}$ enzyme solution and allowed to proceed for $30 \mathrm{~min}$. To terminate the reaction, $0.1 \mathrm{ml}$ $2 \mathrm{~N} \mathrm{HCl}$ is added. The 2,4-dinitrophenylliydrazine reagent $(1.0 \mathrm{ml})$, used in the aldehyde determination, is then pipetted directly into the reaction mixture and the aldehyde determination is completed as described (2).

With each assay at least two $B_{10}$-coenzyme standards and two blanks are included. One blank contains no $\mathrm{B}_{12}$-coenzyme, and the other contains the unknown coenzyme solution but no enzyme. The second blank is generally negligible. All assays are carried out in the dark. Flashlights are used to provide sufficient light to carry out the necessary operations.

The results of a typical assay are shown in Fig. 1. The enzyme used was a highly purified preparation of dioldehydrase. Less highly purifier! preparations have been used and were equally suitable.

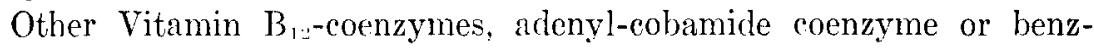

${ }^{1}$ This work was supported by Grant No. GM-012633, National Institutes of Health, USPHS. Contribution No. 418 from the Graduate Department of Biochemistry, Brandeis University, Waltham, Massachusetts.

${ }^{2}$ The following trivial names are used: $\mathrm{B}_{12}$-coenzyme $=5,6$-dimethylbenzimidazolylcobamide-5'-deoxyadenosine; hydroxocobalamin $=5.6$-dimethỵlhenzimidazolylcobamide hydroxide. 


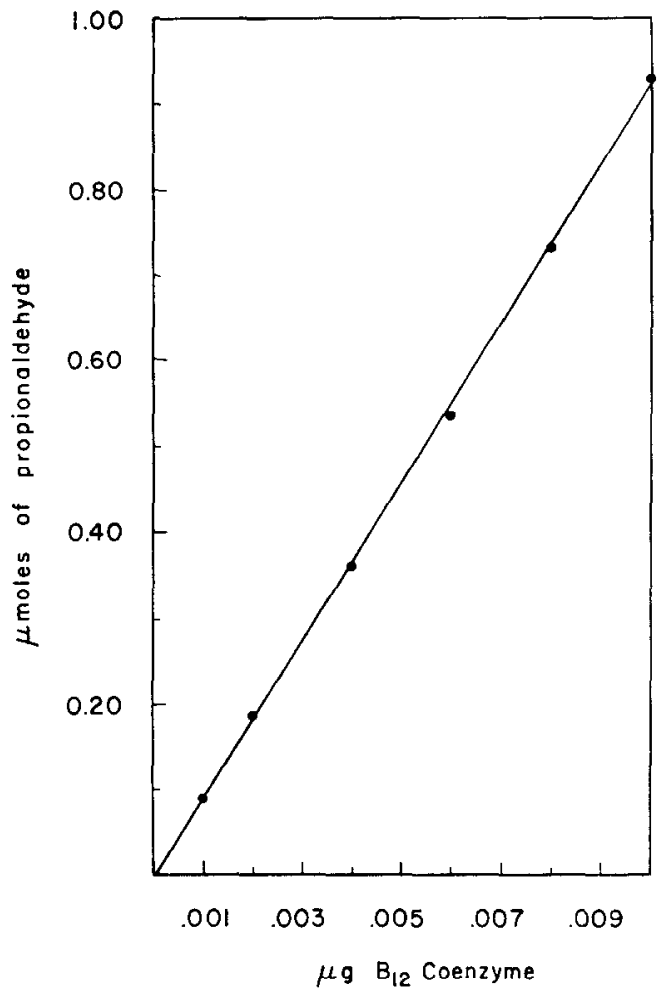

Fig. 1. Assay of $B_{12}$-coenzyme. Assay ronditions as described in the text. Optical densities were determined in a Klett colorimeter with filter No. 54 . Abscisia represents total amount of $B_{1-}$-connzyme in assay tube.

imidazolyl-cobamide coenzyme, activate dioldehydrase as efficiently is $\mathrm{B}_{12}$-cocnzyme (3). It is probable, therefore, that the assay deccribed here is also suitable for these coenzymes. However, since they were not available to us, they were not tested in the assay system deseribed here.

Application of Method. The method hat been used extensively in this

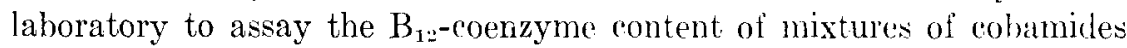
obtained from chemical synthesis or from enzymic reactions in which relatively purc enzymes were used. In all cases the mixtures analyzed were, as a result of preliminary purification or through dilution prior to assay (generally 500 to 1000 -fold), free from salts and other materials that would interfere in the assay. The main sources of potential inhibition of the assay system were other cobamides. These, however, as was pointed out above, do not interfere under the conditions employed. The feasibility of the assay has also heen tested with crude extracts from non mammalian sources. In this case, 1 vol of an atqueous surpension of 
the material to be assayed was added to $10 \mathrm{vol}$ of boiling $95 \%$ ethanol and boiled with stirring for $5 \mathrm{~min}$. The solid was removed and reextracted with half the volume of ethanol of the original extraction. Thr ethanol extract was then brought to dryness under reduced pressure. The residue was taken up in water and an aliquot assayed for coenzyme content. The following are typical results wo obtained: Aerobacter aerogenes (ATCC 8724) $0.5 \mu \mathrm{g} / \mathrm{gm}$ wet cells; Clostridium tetanomorphum (ATCC 3606) $8.5 \mu \mathrm{g} / \mathrm{gm}$ wet cells; Hydra littoralis istarved 24 hr) $0.12 \mu \mathrm{g} / \mathrm{ml}$ packed hydra. Control experiments showed that in no case was any material present in these extracts which interfered with the assay. These assays were carried out primarily to establish that this assay procedure can be used with bacterial extracts of the type employed here. No effort was made to establish whether the extraction procedure quantitatively extracts all the coenzyme. The values obtained are not intended to provide quantitative information regarding the coenzyme content of the organisms examined. The feasibility of the assay, however, has becn established.

\section{REFERENCES}

1. Iee, H. A., Jr., and Abriss, R. H.. J. Biol. Chem. 238, 2367 (1963).

2. Böhne, H., ANd Winkime, O., Z. Areal. Chem. 142, 1 (1954).

3. Abeles, R. H., and Iafe, H. A., JR., J. Biol. Chem. 236, 2347 (1961).

R. H. Abeles

C. MYYers

T. A. SMITH

Graduate Department of Biochemistry

Brande is Universily. Walhom, Massachusett.s

and

Deprotment of Biolugical Chemistry

University of Michigan, Ann Arbor, Michigan

Received Janumy 3. $19 \%$

\section{Interference in Nitrosonaphthol Method of Tyrosine Assay Due to Chloride}

The spectrophotometric (3) and the fluorometric (5) procedures of quantitative tyrosine determination utilize the reaction between this amino acid and 1-nitroso-2-naphthol. The sensitivity of the fluorometric method $\left(5.5 \times 10^{-9}\right.$ mole $)$ is comparable to that ohtained with an anto- 